\title{
Bayer Classification for Corneal Epitheliopathy
}

National Cancer Institute

\section{Source}

National Cancer Institute. Bayer Classification for Corneal Epitheliopathy. NCI Thesaurus.

Code C128435.

A grading system for changes in corneal morphology following treatment with anetumab ravtansine (BAY 94-9343). 